\title{
Academic Exchange and Outreach Projects: Reflexions from an Experience on Refugees, Homeless and Occupations in Brazil and France
}

\section{Projetos de intercâmbio e divulgação acadêmica: reflexões de uma experiência em Refugiados, Sem-teto e Ocupações no Brasil e França}

\author{
${ }^{1}$ Heloisa Teixeira Firmo hfirmo@poli.ufrj.br
}

\begin{abstract}
Environmental engineering students conduct academic exchanges as part of their education. Refugees and homeless in many countries have in common the search for decent housing and basic survival conditions. Today's serious socio-environmental problems must be addressed by professionals who are able to propose effective and lasting solutions. Thus, and seeking to contribute to a full citizen formation of the individual and engineer of today's society, this article describes the experience of a French exchange student from EIVP (Ecole des Ingénieurs de Ville de Paris) in Environmental Engineering at UFRJ (Federal University of Rio de Janeiro) in the MUDA Outreach project, where the student had the opportunity to visit occupations supported by social movements in previously unoccupied places in the metropolitan region of Rio de Janeiro. From reflections on the concept of refugee in Brazil and France, were analyzed and compared initiatives of settlements and homeless in both countries. It is concluded that, although distinct, the displacement crises of individuals and families in both countries have several points in common, highlighting that successful solutions can occur when the main objective is to propose comprehensive social inclusion projects that begin with the consolidation of a new generation of global citizens, which is the main contribution of this work.
\end{abstract}

Keywords: Environmental engineering. Academic exchange. Interdisciplinary studies. Social inclusion. University outreach.

\section{RESUMO}

Estudantes de engenharia ambiental realizam intercâmbios acadêmicos como parte de sua formação. Refugiados e sem-teto, em diversos países, têm em comum a busca por moradia digna e condições básicas de sobrevivência. Os graves problemas socioambientais da atualidade devem ser enfrentados por profissionais capacitados a proporem soluções eficazes e duradouras. Sendo assim e buscando contribuir para uma formação cidadã plena do indivíduo e engenheiro da sociedade atual, no presente artigo, é descrita a experiência de uma aluna de intercâmbio francesa da EIVP (École des Ingénieurs da Ville de Paris) na Engenharia Ambiental da UFRJ (Universidade Federal do Rio de Janeiro) no projeto de Extensão MUDA, onde a estudante teve a oportunidade de visitar ocupações apoiadas por movimentos sociais em locais anteriormente desocupados na região metropolitana do Rio de Janeiro. A partir de reflexões sobre o conceito de refugiado, no Brasil e na França, foram analisadas e comparadas iniciativas de assentamentos e sem-teto nos dois países. Conclui-se que, embora distintas, as crises de deslocamentos de indivíduos e famílias em ambos os países têm diversos pontos em comum, destacando-se que soluções exitosas podem ocorrer quando o objetivo principal é o de propor projetos abrangentes de inclusão social, que começam pela consolidação de uma nova geração de cidadãos globais, sendo essa a principal contribuição desse trabalho.

Palavras-chave: Engenharia ambiental. Intercâmbio acadêmico. Estudos interdisciplinares. Inclusão social. Extensão universitária. 


\section{INTRODUCTION}

The academic world is going through a period of unprecedented growth in student mobility (Harrisson 2015). The program CAPES-BRAFITEC (BRAsil France Ingénieur TEChnologie, CAPES)of academic cooperation between Brazil and France has been providing remarkable results in the training of Brazilian and French students, especially in recent years, when many of them pursued a double undergraduate degree.

During the last 10 years, I have acted both as a coordinator of BRAFITEC and outreach projects at UFRJ (Federal University of Rio de Janeiro), notably the project MUDA (MUDA 2020). These projects propose a sort of engineering teaching in which students interact with communities, so as to breach "academic walls" and devise technical solutions that are compatible with users' reality. The concept of "academic walls" in this context refers to a usual attitude of some universities that concentrate knowledge in order to allow the production of articles and publications in general, without actually assuming a transforming role in pressing societal problems, in particular those related to social issues concerning marginalized groups. By assuming a more social attitude, it may be possible to conceive technical solutions compatible with the reality of users; in other words, to promote the use of social technologies, which comprehend more just and inclusive low cost and easier to replicate devices or processes. Much of these communities in underdeveloped countries are constituted by the poorer strata of society and lack many services. Contributions from many fields of study and research in Environmental and Civil Engineering - such as housing, sanitation, healthy food, food sovereignty, waste management and construction — could greatly improve that situation.

In this direction, a French exchange student during five months in 2017, to bring together her past experience of participation in outreach projects in France and an internship of five months in the MUDA Outreach project (MUDA 2020)

The lessons learned from an experiment like the one described here may contribute to provide an active learning to undergraduate Engineering students both of their role as technicians and citizens in a plural society. For Raghallaigh and Cunniffe (2013), in recent years a growing body of literature and research has recognised the value of active learning experiences for students. Active learning involves experiences, as well as a reflection on what and how one is learning. Through reflection, either alone or with fellow students, the meaning of experiences and ideas can be apprehended.

\section{METHODOLOGY}

In France, political, cultural, social and economic expatriation of refugees and their struggle for housing is intertwined with the fight for survival in a country where they have little or no cultural or political affinity, besides the crucial difficulty of an unfamiliar language. The number of people currently living in such risky conditions in France reaches four million, according to the Abbé Pierre foundation (Abbé Pierre 2018).

A situation like this shows a great similarity with the condition of low-income Brazilians who, by being politically and economically excluded, have few and precarious housing alternatives apart from the favelas, streets or squats. Two examples of the latter are the ones organized by the National Movement for Housing Struggle (MNLM or Movimento Nacional de Luta pela Moradia, in Portuguese), which claims to act under a City Statute (Brasil 2001), which ensures that under certain conditions, people have the right to occupy specific municipal areas. The squats are Manuel Congo, situated in a building in downtown Rio de Janeiro and Solano Trindade, an area of $45.000 \mathrm{~m}^{2}$ located in Duque de Caxias, a municipality in the metropolitan area of Rio de Janeiro. 
The hypothesis to be tested in the experiment of the exchange student was to access whether her academic and cultural baggage, when contrasted with the reality of conditions in Brazil, was able to provide some relevant educational insights. In other words, whether the participation in the project and the subsequent analysis of similarities and contrasts of occupations in Brazil and France, could lead to an improvement of the student's training both as an engineer and a citizen, thus paving the way for similar experiments with other students in Brazil and abroad.

The data collection consists of the process of acquiring knowledge of the reality to be interpreted through qualitative research of the phenomena to be investigated. In the method of analysis chosen for this study — akin to the anthropological approach of "participant observation" - the search for qualitative aspects as the adopted method proves to be as important and perhaps more effective than a quantitative methodology (Lapassade, 2001). Along those lines, an exchange student from the EIVP - École des Ingénieurs de la Ville de Paris was a 'participant observer' of the Manuel Congo and Solano squats, through all day visits along five months in 2017 The purpose of these visits was to bring together her past experience as a participant in outreach projects in France and an internship of five months in the MUDA Outreach project. By the end of the exchange period, the student went back to France, continuing the research through bibliographic material to consolidate the practical experience. Results of these processes were organized and summarized in Tables 1 and 2.

\section{THE PRECARIOUSNESS OF HOUSING AND THE URBAN CRISIS}

In the western world nowadays, ubiquitous social exclusion is a consequence of the growing number of divisions, fractures and social inequalities that are mainly expressed and visible within the city (Guerra 2012). According to Byrne (2005) the term 'exclusion' is inherently dynamic, since exclusion happens in time, in a period of history and 'determines' the lives of the individuals and collectivities who are excluded or not. For Guerra (2012), social inclusion implies the dynamic and proactive provision of welfare which involves more than breaking through, for it requires investments and capabilities in order to potentialize and develop conditions to inclusion.

Although housing circumstances in Europe and France seem to be not comparable to those in Brazil, there are - perhaps surprisingly — several similarities. In what follows I present an outlook of low-income housing in the city of Rio de Janeiro, Brazil and in France, where those similar conditions become apparent.

\section{LOW INCOME HOUSING IN RIO DE JANEIRO}

The dimensions of displacement in Brazil are only gradually being recognized. Although there is speculation that between 2009 and 2016 some 1.5 million Brazilians were forcibly evicted because of World Cup and Olympics preparations, there are no firm empirical studies to back these claims (Muggah 2014)

According to the latest census by the Brazilian Institute for Geography and Statistics (IBGE 2010), an estimated 11.5 million people in Brazil live in slums, out of a total population of approximately 200 million. The IBGE defines slum (favela) as a 'subnormal settlement' (off legal housing code). More specifically, as a "subnormal cluster consisting of at least 51 housing units, occupying or having occupied until recently, privately or public owned land in a disorderly and dense manner, as well as lacking, for the most part, essential public services”. The inclusion in the IBGE's definition of the terms "disorderly and dense” as well as "occupying (...) private or public owned land” do not encompass all levels of precariousness and vulnerability, sometimes extreme, of certain urban agglomerations known as favelas.

The city of Rio de Janeiro (the second largest in the country) has a population of 6.3 million people or 15.9 million, when its entire metropolitan area is included, according to the 2010 IBGE census, with a total of 1,035 favelas catalogued. The favelas arise mainly through massive migrations from northern regions of the country 
to the south, which is more urbanized and developed. Currently, Rio de Janeiro is the city with the highest proportion of slum dwellers in Brazil. Due to the country's present economic crisis, plus the increase of the city's public debt due the 2016 Olympic Games investments, this number is likely to grow.

Brazilian public policy concerning housing for lower income people was devised by the Workers Party (PT) federal administration. Coming to power in 2003, PT created the Ministry of Cities, which six years later implemented the program "My House My Life" or MCMV - Minha casa minha vida. Its goal was to provide housing for families in conditions of extreme poverty, many of them living in poor shanty towns, and thus to transform informal housing into decent legalized housing. Its initial target was to build 1 million houses, but it has greatly surpassed that goal, reaching by 2016 a total of 3.3 million residential units, with a project to build 4.5 million more. About 12 million people have benefited from the program.

Although the MCMV Programs seems irreproachable, they faced many criticisms. In fact, the MCMV has made many mistakes, akin to those of similar programs in the 1950s' Europe, where devastating social, urban and constructive consequences are well known. In short, they echoed the way public policies attempt to address housing shortages, by producing popular dwelling units in the same manner as if nothing has changed since the advent of the industrial age. So, the units are located in outlying areas, where costs are generally lower, and almost always lacking proper transportation services, which creates further difficulties for dwellers to reach their workplaces. The MCMV has two types of Programs. In the first (Business), families request financial support independently. The Entity Program is directed to families organized in cooperatives, associations, movements, or any other entity.

\section{PRECARIOUS HOUSING IN FRANCE}

As Tony Judt wrote in his book about post war Europe (JUDT, 2005), there is nowadays in France - and for that matter in the European Union - a "new under-class consisted of people excluded not so much from work as from 'life chances': individuals stranded outside the economic mainstream, their children poorly educated, their families marooned in barrack-like apartment blocks at the edge of cities, bereft of shops, services and transport. (...) [S]uch people lived in urban ghettos blighted by social exclusion, racial discrimination and high levels of domestic violence. In some of these quartiers chauds youth unemployment had reached 50 percent; the worst affected were young people of Algerian or Moroccan descent.”

This is a most troubling situation. The Abbé Pierre (2018) foundation has released in 2018 a report on precarious housing in France, showing that 12.1 million people are affected by the housing crisis. Around 16,000 people were identified in April 2017 as living in illegal camps, large squats or bidonvilles (slums), in 571 locations, with 113 (20\%) in Ile-de-France. For sure, homeless French citizens, who were victims of difficult social situations or economic crises, Gypsies and other exiled populations have always been part of this under-class, but the situation has deteriorated and become especially complex since 2010, with the migratory crisis in Europe. Migration, boosted by more than 1 million applications per year for asylum in Europe, in 2015 and 2016, made the situation even worse. France is one of the countries that receive a great flow of migrants, who comprise clandestine populations as well.

For a rather long time, a large number of exiles were "piled up" in an area known as the "Jungle of Calais" (The Economist 2015). This self-built, very publicized and controversial space, located in a region close to England, was one of the largest contemporary bidonvilles in France, with more than 5,000 residents by 2015. Its definitive removal occurred in 2017 without, however, an effective solution for a replacement. The removal of the Jungle of Calais has provoked several illegal micro-occupations in France, such as that in the Eole Garden, in the 19ème arrondissement of Paris, which sheltered 800 migrants for several weeks. Its present (unsuccessful) attempt to rebuild has led to an increasing precariousness and instability of exiles in France. 
Nevertheless, some alternative solutions have been proposed. In the town of Grande-Synthe, near Calais, there was another bidonville similar to the Jungle of Calais, called the Basroch jungle. In the winter of 2015, the city's Municipality built a humanitarian refugee camp based on international standards, which was the first ever to be built in France. The Grande Synthe field was very popular with the media and showed a political will to act and accommodate refugees, although some of them were illegal immigrants. On the other hand, it highlighted a lack of planning for humanitarian fields, which despite the name consisted of tight spaces, were unhealthy, isolated from the world and militarized. These circumstances perhaps explain how such alienating space generated internal conflicts, which resulted in a fire that decimated more than half the field and eventually led to its closure.

On a brighter note there is another initiative that signals some hope. The former hospital Saint-Vincent-de-Paul in the 14th arrondissement of Paris has been occupied since 2012 by the Aurore association (http: // aurore.asso.fr/), through a partnership with APHP - Assistance Publique-Hôpitaux de Paris and the city of Paris. Aurore specializes in emergency housing for vulnerable people through the project "Les Grands Voisins" (The Great Neighbors) and APHP is the present responsible for the hospital property. However, the City of Paris has acquired the property for the development of a new district for the city, with the goal of building 600 new housing units. The construction project was to begin in 2017, but the challenge was for Aurore to use the potential of this extraordinary space before the actual works began.

Since 2015, another institution, the Plateau Urbain association (https://www.plateau-urbain.com/) has supported Aurore in the coordination of housing projects. The Yes We Camp association (http://yeswecamp.org/) helps to encourage meetings among local residents, with the purpose of disclosing to the public the actions being taken. Today, 600 people live in Aurore's emergency care centres, where about 1,000 people have their offices or workshops. By December 2017, the Aurore's website received between 500 and 1500 visitors a day, for various workshops and events: parties, gardening workshops, conferences, etc.

\section{DESIGN/METHOD}

The internship began with the student's training in the project MUDA, with activities performed at the UFRJ campus. Thereafter, visits were made to two MNLM occupations (Manuel Congo and Solano Trindade). They consisted of one-day and weekend stays, during which the student participated in workshops on bio-construction, harvesting and preparation of healthy food produce, housing construction and agro-ecological gardening.

The Manuel Congo and Solano Trindade squats are examples of innovative ways to handle housing issues for low-income citizens.

In its mission to help the homeless, the MNLM has achieved an expressive victory with the occupation Manuel Congo, which is considered to be a model. After many years of continuous struggle, $97 \%$ of the work for construction of 42 housing units has been completed, thanks to the financing of the MCMV1's Entity program.

The site of the Solano Trindade (OM 2017) occupation in the municipality of Duque de Caxias, in the State of Rio de Janeiro, was carried out by the MNLM in August 2014. The land was granted to the Movement by the Federal Secretariat of Patrimony, for the specific purpose of implementing a housing project. In addition, the project provides for the deployment of a transdisciplinary experimental campus for technical cooperation between MNLM and UFRJ, in order to enlarge the resident's worldview. Activities are structured around mutirões (social joint efforts), with tasks like the building of the roof of the occupation's communal kitchen, made with pieces of wood donated by UFRJ. Financial support for this activity was devised through a "crowd-funding", with phases of R $\$ 30,000$ targets. The first target was reached by November 2017. The Solano Trindade occupation currently has capacity for housing ten families, and the MNLM adopts a careful selection of new families, who undergo preparatory training to be part of the movement. 
In order to facilitate the construction of new housing, the MNLM is collaborating with the School of Architecture and the Institute for Urban and Regional Planning of UFRJ, to create a centre called "Experimental Factory of Cities. Its purpose is to experiment with constructive techniques and people's education, in order to increase their power and citizenship, so as to enable them to think and create the city.

\section{$7 \quad$ RESULTS}

Tables 1 and 2 present a summary of the main initiatives for settlement of 'homeless' individuals in Brazil and France, respectively. It can be seen from the tables that if occupations are well and inclusively planned, results can be quite significant. In other words, if reallocations primary goal is not merely to meet numerical targets, there can be profound and effective societal changes. Isolated initiatives, such as that of the Grande-Synthe city in France, highlight the fragility of solutions that are not built collectively, and may cause tensions and upheavals that lead to failure.

The proposals of the MNLM movement are still not quite accepted, as what they recommend for the city is not yet fully compatible with current public policy. The term "occupation" itself represents a view contrary to those policies. Even when occupiers are not expelled from their settlement, official funding to simple housing projects remains an issue, especially in the case of collective spaces. Nevertheless, the idea of collective citizen's initiatives, particularly those in which low-income Brazilians are involved, represent a way for people to make their voice heard. Additionally, by extending the concept of decent housing to the provision of collective spaces, with specific goals, as well as by putting into practice partnerships with universities and research laboratories, the MNLM model provides a comprehensive alternative to current urban planning approaches.

The long lasting Manuel Congo occupation in Rio shows that the MNLM alternative is capable of presenting tangible results. The same can be said of the Solano Trindade occupation, which provided the means for an intense cooperation with UFRJ. This cooperation benefited both partners and demonstrates an intention to redefine the direction of the university's action, from the absolute holder of knowledge to a companion in a multidisciplinary learning process.

Les Grands Voisins projects are in many ways similar to MNLM occupations in proposals for housing and the city. They both favour the occupation of abandoned buildings within the city, because they are spaces that already have a structure, a ceiling and are integrated in the urban fabric and city life. This type of solution also addresses the question of providing decent emergency housing. It also deals with the issue of temporality, i.e. building houses expeditiously does not necessarily mean to do it in an arbitrary and non-inclusive manner. Temporary housing should provide similar services as perennial dwellings, albeit in simpler ways.

In present-day society, where the flow of information is abundant, citizens, either natives or refugees, know quite clearly what dignity means. Collective solutions resulting from partnerships among NGOs, social movements and universities can enrich the dialogue, strengthen and perpetuate the rights of people. The construction of democracy is not an easy task, but one thing is certain: the more people participate in solutions to societal problems, the more robust and resilient they are against any social disturbances.

\section{CONCLUSIONS.}

In a way, the situation of "Brazilian refugees in Brazil" is quite similar to that of refugees in France and elsewhere, in their struggle to survive. This underclass is relegated to live wherever they can, in the countryside, streets, squares, alleys and viaducts. By not being able to live with dignity, refugees, migrants, exiles or low-income citizens in any country have their inalienable rights taken away. 
Refugee camps, favelas, shanty towns, bidonvilles, which are always subjected to the pressure of removal, are not real solutions, but only subterfuges found by those trying to survive. Official programs such as the MCMV do not offer real solutions to providing dignity and actual citizenship. Initiatives like the MNLM and other social movements in Brazil or associations in France underline the need to reconsider the modes of governance of our democracies. The reuse of neglected existing spaces in the city sheds light to another way of thinking the town through the concept of social function of property.

As Harrison (2015) points out, "worldwide problems require the intervention of a new generation of 'global citizens' who are equipped with an awareness of the interconnectedness of the modern world and the agency to initiate change." In this sense, the participation in a hand-on experiment provided by the MUDA outreach project in Brazil has allowed the French exchange student to reflect about the significant impacts that Engineering and environmental education, when linked to the notion of citizenship, can have in proposing appropriate and effective solutions to society's many problems.

Table 1 Summary of the main initiatives for settlement of 'homeless' individuals in Brazil (BR).

\begin{tabular}{|c|c|c|c|}
\hline Program & Type & Positive Aspects & Negative Aspects \\
\hline $\begin{array}{l}\text { MCMV - } \\
\text { Business }\end{array}$ & Public Policy & $\begin{array}{l}\text { Achieved impressive nu- } \\
\text { merical goals. }\end{array}$ & $\begin{array}{l}\text { Generates further exclusion; } \\
\text { Aims to achieve numerical goals; } \\
\text { No concerns about structures to promote citizenship; } \\
\text { Poor transportation services; } \\
\text { Difficult access to cultural centres; } \\
\text { Exclusion from city services and benefits. }\end{array}$ \\
\hline MCMV - Entity & Public Policy & $\begin{array}{l}\text { Aimed at families orga- } \\
\text { nized in cooperatives. }\end{array}$ & $\begin{array}{l}\text { Applies only to the financing of housing construc- } \\
\text { tion (R\$ } 75 \text { thousand per unit); } \\
\text { No provision for community services; } \\
\text { Poor performance in terms of number of housing } \\
\text { units built. }\end{array}$ \\
\hline $\begin{array}{l}\text { MNLM Manuel } \\
\text { Congo RJ }\end{array}$ & $\begin{array}{l}\text { Implemented } \\
\text { by a social } \\
\text { movement, with } \\
\text { resources from } \\
\text { MCMV-Entity } \\
\text { Program }\end{array}$ & $\begin{array}{l}\text { Provides common spaces, } \\
\text { public and semi-public, with } \\
\text { various purposes, mainly } \\
\text { designed for the organiza- } \\
\text { tion of the work of the } \\
\text { cooperative; } \\
\text { Achieved excellent results. }\end{array}$ & $\begin{array}{l}\text { Demands constant political and social formation } \\
\text { of members of the cooperative; } \\
\text { May present future legal problems regarding the } \\
\text { definition of building ownership. }\end{array}$ \\
\hline & $\begin{array}{l}\text { Implemented } \\
\text { by a social } \\
\text { movement, with } \\
\text { resources from } \\
\text { MCMV-Entity } \\
\text { Program }\end{array}$ & $\begin{array}{l}\text { Innovative approach; } \\
\text { Proposes alternative solu- } \\
\text { tions for the construction of } \\
\text { dwellings; } \\
\text { Implemented a project for } \\
\text { generating work and income } \\
\text { through technical training. }\end{array}$ & $\begin{array}{l}\text { Presently faces difficulty in obtaining resources; } \\
\text { Collaborative funding has not achieved enough } \\
\text { support to carry on projects. }\end{array}$ \\
\hline
\end{tabular}


Table 2 Summary of the main initiatives for the settlement of homeless individuals in France (FR).

\begin{tabular}{|c|c|c|c|}
\hline Program & Type & Positive Aspects & Negative Aspects \\
\hline Calais Squat & Squat & $\begin{array}{l}\text { Provided temporary housing for set- } \\
\text { tlers until they were granted asylum } \\
\text { to reunite with family members in the } \\
\text { United Kingdom. }\end{array}$ & $\begin{array}{l}\text { Symbol of the situation of Europe's under- } \\
\text { class; } \\
\text { Lawless area, with no State protection and } \\
\text { minimum human rights. }\end{array}$ \\
\hline Grand Synthe Squat & $\begin{array}{l}\text { Humanitarian } \\
\text { refugee camp }\end{array}$ & $\begin{array}{l}\text { Officially created by the Municipal- } \\
\text { ity of the city of Grande-Synthe, under } \\
\text { international codes. }\end{array}$ & $\begin{array}{l}\text { Lack of planning for social needs; } \\
\text { Tight and unhealthy spaces; } \\
\text { Isolated and militarized; } \\
\text { Prone to internal conflicts (led to a fire that } \\
\text { wiped out more than half of the camp). }\end{array}$ \\
\hline $\begin{array}{l}\text { "Les grands voisins" } \\
\text { Project, - Sint Vincent } \\
\text { Hospital }\end{array}$ & $\begin{array}{l}\text { Partnership be- } \\
\text { tween City of Par- } \\
\text { is, Aurore, Plateau } \\
\text { Urban and Yes we } \\
\text { Camp associations }\end{array}$ & $\begin{array}{l}\text { More than } 600 \text { people live in the } \\
\text { project's emergency care centre; } \\
\text { About } 1000 \text { people have their offices } \\
\text { or workshops in the project's prem- } \\
\text { ises; } \\
\text { Project's website site provides list- } \\
\text { ings for various workshops and con- } \\
\text { ferences (has a daily average of } 1000 \\
\text { visits). }\end{array}$ & $\begin{array}{l}\text { Despite very good results, this project will } \\
\text { come to an end because the city of Paris has } \\
\text { an urban renewal plan for the area; } \\
\text { An alternative project, scheduled to be } \\
\text { completed by } 2020 \text { will not be strictly fo- } \\
\text { cused on the "poorest." }\end{array}$ \\
\hline
\end{tabular}

Source: prepared by the author.

\section{ACKNOWLEDGEMENTS}

I would like to thank Christelle Caroline Noelle Davrieux, who collaborated in this research and provided invaluable information for this paper.

\section{DISCLOSURE STATEMENT}

No potential conflict of interest is reported by the author. 


\section{REFERENCES}

ABBÉ PIERRE Foundation, Raport 23, 2018.

BRASIL, LEI No 10.257, de 10 de julho de 2001 [Law number 10.257 July 10 2001].

BYRNE, David. Social exclusion. McGraw-Hill Education (UK), p. 2, 2005.

GUERRA, Paula. Da exclusão social à inclusão social: eixos de uma mudança paradigmática. Revista Angolana de Sociologia, n. 10, p. 91-110, 2012.

HARRISON, N. 2015. "Practice, problems and power in 'internationalisation at home: critical reflections on recent research evidence”, Teaching in Higher Education, 20:4,412-430, DOI: 10.1080/13562517.2015.1022147.

IBGE, Instituto Brasileiro de geografia e Estatística, Censo, 2010.

JUDT, Tony. 2005. Postwar: A History of Europe Since 1945, The Penguin Press, New York.

LAPASSADE, Georges. L'observation participante. Revista Europeia de Etnografia da Educação, v. 1, n. 1, p. 9-26, 2001.

"Learning from the Jungle". 2015. The Economist, August 6, Accessed on October 14 2020, https://www. economist.com/europe/2015/08/06/learning-from-the-jungle.

M. Ní Raghallaigh \& R. Cunniffe (2013) Creating a safe climate for active learning and student engagement: an example from an introductory social work module, Teaching in Higher Education, 18:1, 93-105, DOI: 10.1080/13562517.2012.694103

MUDA, 2020. “Mutirão De Agroecologia” [Joint effort of agroecology]. Accessed October 14 2020. http:// www.muda.poli.ufrj.br

MUGGAH, Robert. "The invisible displaced: a unified conceptualization of population displacement in Brazil.” Journal of Refugee Studies 28.2 (2015): 222-237.

O.M. - Observatório das Metropoles, 2017, 30 August, Accessed on October 14 2020, http:// observatoriodasmetropoles.net.br/wp/fabrica-experimental-de-cidades-solano-trindade-2 